\title{
Implicit cognition as a moderator of brief motivational interventions for alcohol
}

\author{
Tibor Palfai ${ }^{* *}$, Brian Ostafin ${ }^{2}$ \\ From International Network on Brief Interventions for Alcohol Problems (INEBRIA) Meeting 2011 \\ Boston, MA, USA. 21-23 September 2011
}

Hazardous alcohol use is a function of implicit cognition, i.e., nonconscious influences on appetitive behavior stemming from memory associations that are automatically activated upon exposure to alcohol cues. Implicit cognition is typically not addressed by alcohol brief intervention (BI), which targets explicit or conscious processes underlying alcohol restraint (e.g., readiness-to-change). The potential role of implicit cognition in BI outcomes has not been well-studied. Eighty-nine hazardous drinking college students (Alcohol Use Disorders Identification Test [AUDIT] score > 8) participated in a general health study for course credit. Students were randomly assigned to one of two conditions: assessment only or a 10-15 minute motivational intervention. Students completed measures of alcohol use and readiness-to-change at baseline and at 6-week follow-up. In addition, they completed an alcohol-specific implicit association test (a response-time measure of alcohol approach). The motivational intervention resulted in a significant increase in readiness-to-change immediately following the intervention. However, the effect of the intervention on change in quantity of alcohol use per drinking occasion at followup was significantly moderated by implicit cognition. Simple slopes analyses showed that those with low implicit appetitive responses showed significantly less drinking when exposed to the intervention condition, while those with high implicit cognition did not. Similarly, readinessto-change scores predicted declines in drinking for those low in implicit cognition but not for those who showed high levels of implicit cognition. These results suggest that the effect of brief motivational intervention may be less effective among those with strong implicit alcoholapproach associations, and that implicit cognition may be important to address in subsequent BI development.

Department of Psychology, Boston University, Boston, MA, USA

Full list of author information is available at the end of the article

\section{Author details}

'Department of Psychology, Boston University, Boston, MA, USA.

${ }^{2}$ Addictive Behaviors Research Center, University of Washington, Seattle, WA, USA.

Published: 9 October 2012

doi:10.1186/1940-0640-7-S1-A46

Cite this article as: Palfai and Ostafin: Implicit cognition as a moderator of brief motivational interventions for alcohol. Addiction Science \& Clinical Practice 2012 7(Suppl 1):A46.
Submit your next manuscript to BioMed Central and take full advantage of:

- Convenient online submission

- Thorough peer review

- No space constraints or color figure charges

- Immediate publication on acceptance

- Inclusion in PubMed, CAS, Scopus and Google Scholar

- Research which is freely available for redistribution

Submit your manuscript at www.biomedcentral.com/submit
() Bïomed Central
C Biomed Central

() 2012 Palfai and Ostafin; licensee BioMed Central Ltd. This is an Open Access article distributed under the terms of the Creative Commons Attribution License (http://creativecommons.org/licenses/by/2.0), which permits unrestricted use, distribution, and reproduction in any medium, provided the original work is properly cited. 